\title{
RECONSIDERING DOMESTIC SALE OF GOODS REMEDIES IN LIGHT OF THE CISG
}

\author{
Nicholas Whittington*
}

\begin{abstract}
This article suggests that New Zealand should overhaul the remedies available for breach of sale of goods contracts. It argues that the Sale of Goods Act 1908 should be repealed and the principles and provisions of the United Nations Convention on Contracts for the International Sale of Goods 1980 (CISG) should be adopted in its place. This would have the effect of eliminating the unnecessary distinction currently made between domestic and international sale of goods, and finally ridding the law of the condition-warranty distinction which has become out of date and leads to uncertainty and injustice. It is argued that the provisions of the CISG better respond to the transportation and communication costs and distances involved in international sales, considerations which are not insignificant in trade within New Zealand and, consequently, justify a similar approach domestically.
\end{abstract}

\section{INTRODUCTION}

The remedies available for breach of contract in New Zealand may be found in any one of four statutory codes, depending on the particular characteristics of the contract. ${ }^{1}$ This situation is unsatisfactory, ${ }^{2}$ adds undue complexity to the law, increases compliance costs and is, therefore, indefensible.

* Submitted as part of the LLB (Hons) programme at Victoria University of Wellington. Joint Recipient of the 2005 Colin Patterson Memorial Prize.

1 These are: the Consumer Guarantees Act 1993 for consumer sales of goods and services, the Sale of Goods Act 1908 for domestic sales of goods other than consumer sales, the United Nations Convention on Contracts for the International Sale of Goods (11 April 1980) 1489 UNTS 3 [CISG] for international sales of goods, and the Contractual Remedies Act 1979 for all other contracts.

2 This was the descriptor used by the New Zealand Law Commission in 1993. See D F Dugdale and C T Walker "Harmonisation of the Sale of Goods Act 1908 and the Contractual Remedies Act 1979" in New Zealand Law Commission Contract Statutes Review (NZLC R25, Wellington, 1993) 112. 
This article proposes that the remedial provisions of the Sale of Goods Act 1908 be repealed and a new set of provisions based entirely on the principles and rules found in the United Nations Convention on Contracts for the International Sale of Goods 1980 (CISG) $^{3}$ be adopted in their stead. This would create the following legal framework:

(a) The Consumer Guarantees Act 1993 for consumer sales;

(b) The CISG provisions for sale of goods contracts, whether domestic or international, other than those involving consumers; and

(c) The Contractual Remedies Act 1979 for all other contracts.

This article will consider four main reasons why such a position should be adopted.

First, the current New Zealand law relating to termination of sale of goods contracts has become uncertain. It is argued that the CISG's provisions for avoidance of the contract provide a more just and certain legal response to breach of a sale of goods contract.

Secondly, the CISG's remedies specifically reflect the transportation costs, communication costs and distances involved in international sales. These same considerations are not insignificant in trade within New Zealand and justify a similar approach domestically.

Thirdly, such an approach would assist New Zealand's export and import sectors. Reducing legal costs by having a uniform law for sale of goods contracts would help New Zealand companies in achieving the economies of scale necessary to compete in overseas markets, and assist the growth of the economy.

Fourthly, such a step would not be unprecedented. The harmonisation of domestic and international rules relating to sale of goods contracts has to various extents taken place in the People's Republic of China, Scandinavia, Germany and the successor States of Yugoslavia. ${ }^{4}$

After an examination of the current New Zealand law concerning termination for breach of contract, the principles and provisions of the CISG will be considered.

3 The CISG, above n 1, was incorporated into New Zealand law by the Sale of Goods (United Nations Convention) Act 1994. The CISG was prepared by the United Nations Commission on International Trade Law (UNCITRAL) and adopted by a United Nations diplomatic conference on 11 April 1980: see the Explanatory Note by the UNCITRAL Secretariat on the United Nations Convention on Contracts for the International Sale of Goods, Pace Law School CISG Database <http://www.cisg.law.pace.edu $>$ (last accessed 3 August 2006) Introduction, para 1 [Explanatory Note]. It entered into force on 1 January 1988 and to date has 65 contracting States Parties: see UNCITRAL $<$ http://www.uncitral.org $>$ (last accessed 3 August 2006).

4 Peter Schlechtriem Commentary on the UN Convention on the International Sale of Goods (CISG) (2 ed, trans, Oxford University Press, Oxford, 1998) 7 [Schlechtriem Commentary]; Hans Schulte-Nölke "The New German Law of Obligations: an Introduction" (2002) German Law Archive $<$ http://www.iuscomp.org/gla/index.html > (last accessed 3 August 2006). 


\section{TERMINATION FOR BREACH IN NEW ZEALAND}

On a breach of contract justifying termination, the innocent party obtains the right to terminate the contract. In sale of goods contracts this may permit an innocent buyer to refuse to pay the price or to reject the goods on delivery, or may permit an innocent seller to refuse to deliver the goods. In effect, termination "undoes" the contract, ${ }^{5}$ although "undoing" the contract does not deprive the injured party of its right to claim damages. ${ }^{6}$

\section{A Importance and Effects of Termination}

Termination is an important remedy because it "avoids the need to go to court". ${ }^{7}$ If a seller delivers goods that are useless for the buyer's intended use because they breach an implied condition, ${ }^{8}$ rejection of the goods and refusal to pay the price will allow the buyer to avoid the rigmarole of accepting the goods and paying the price, and at the same time beginning proceedings for the amount paid minus any money it can get for reselling them. Instead the buyer can simply obtain the goods elsewhere at the current market value. ${ }^{9}$

Considering that the remedy of termination is so far-reaching, the law only permits its exercise in certain circumstances. Only the breach of some contractual terms will lead to termination being available. There exist three types of contractual terms. The first is a condition, ${ }^{10}$ the breach of

5 See Guenter Treitel Some Landmarks of Twentieth Century Contract Law (Oxford University Press, Oxford, 2002) 107 [Treitel Landmarks].

6 Photo Production Ltd v Securicor Transport Ltd [1980] AC 827, 851 (HL) Lord Diplock.

7 Treitel Landmarks, above n 5, 109. See also Hugh Beale Remedies for Breach of Contract (Sweet \& Maxwell, London, 1980) 2 [Beale Remedies]; Patrick S Atiyah An Introduction to the Law of Contract (5 ed, Oxford University Press, Oxford, 1995) 421.

8 The Sale of Goods Act 1908 contains a number of conditions which are implied into every contract except where the parties expressly provide for the contrary. Examples include correspondence to the contractual description (s 15), reasonable fitness for a particular purpose made known to the seller (s 16(a)), and merchantable quality (s 16(b)).

9 Sale of Goods Act 1908, s 52(3). If the market rate has fallen or remained static the buyer will have no loss and no need to begin proceedings, though nominal damages may be claimed. If it has risen, the buyer will be able to obtain the difference between the current market rate and the original contract price from the seller: see John Burrows, Jeremy Finn and Stephen Todd (eds) Law of Contract in New Zealand (2 ed, LexisNexis Butterworths, Wellington, 2002) 751; Wertheim v Chicoutimi Pulp Co [1911] AC 301, 307 (PC) Lord Atkinson.

10 Although "condition" is not defined in the Sale of Goods Act 1908, it is clear from the words of section 13(2) of the Act that a distinction must be made. The most common definition is that it is a term that goes to the root of the contract: see for example Davidson $v$ Gwynne (1810) 104 ER 149, 152 (KB) Lord Ellenborough CJ; Glaholm v Hays, Irvine and Anderson (1841) 133 ER 743, 747 (CP) Tindal CJ; Bettini v Gye (1876) 1 QBD 183, 188 (QB) Blackburn J. A more modern formulation of "condition" is a term the breach of which "will deprive the party not in default of substantially the whole benefit which it was 
which gives rise to the right to terminate the contract. The second is a warranty, ${ }^{11}$ the breach of which only gives rise to the right to damages. The third is an intermediate term, ${ }^{12}$ the breach of which gives rise to the right to terminate the contract only if the consequences are sufficiently serious, and otherwise gives rise only to the right to damages. ${ }^{13}$ Whether a breach of an intermediate term leads to the right to terminate the contract depends on the gravity of the breach for the innocent party. ${ }^{14}$ If the consequences of the breach are at the serious end of the spectrum, the remedies attributable to a breach of condition will be available. ${ }^{15}$ If the consequences are at the minor end of the spectrum, the innocent party will be restricted to claiming damages. ${ }^{16}$

\section{B Reasons for Reform of This Position}

There is no doubt that the law relating to sale of goods contracts in New Zealand was intended to create certainty. Maintaining the certainty of the rules may be why Parliament removed sales of goods from the ambit of the Contractual Remedies Act 1979 when it revamped the law relating to termination of contracts in that Act. ${ }^{17}$

However, this article argues that this position is unsatisfactory for two reasons. The first reason is that there is no point in having certain rules where they are out-dated and unworkable in today's world. The second reason is that it can no longer be said that the rules promote certainty. In some cases the rules may even lead to injustice.

intended that he should obtain from the contract." See Hong Kong Fir Shipping Co Ltd v Kawasaki Kisen Kaisha Ltd [1962] 1 All ER 474, 487 (CA) Diplock LJ [Hong Kong Fir Shipping].

11 A warranty is an agreement concerning the goods to be sold which is "collateral to the main purpose" of the contract: Sale of Goods Act 1908, s 2(1). It is a contractual term of which it can be said that "no breach ... will deprive the party not in default of substantially the whole benefit which it was intended that he should obtain from the contract." See Hong Kong Fir Shipping, above n 10, 487 Diplock LJ (emphasis in original).

12 An intermediate term is one which, by its very nature, defies classification as a condition or warranty. Instead, the effects of an intermediate term depend "on the nature of the event to which the breach gives rise and do not follow automatically from a prior classification of the undertaking as a 'condition' or a 'warranty'." See Hong Kong Fir Shipping, above n 10, 487 Diplock LJ.

13 Guenter Treitel The Law of Contract (11 ed, Sweet \& Maxwell Ltd, London, 2003) 796 [Treitel Contract].

14 Hong Kong Fir Shipping Co, above n 10, 487 Diplock LJ. For example, in Holmes v Burgess [1975] 2 NZLR 311 (SC) the plaintiff made a contractual representation that a horse to be sold was "sound as a bell". Casey $\mathrm{J}$ held at 317-318 that the representation was an intermediate term, such a statement being reasonably capable of covering anything from a "small and readily cured defect right through to a permanent and serious deformity rendering [the horse] useless."

15 Federal Commerce \& Navigation Ltd v Molena Alpha Inc [1979] AC 757 (HL); Treitel Contract, above $\mathrm{n}$ 13,795 .

16 Hong Kong Fir Shipping, above n 10; Cehave NV v Bremer Handelsgesellschaft mbH (The Hansa Nord) [1975] 3 All ER 739 (CA); Treitel Contract, above n 13, 795.

17 Contractual Remedies Act 1979, s 15(d). 


\section{The rules are out-dated}

The Sale of Goods Act 1908 (the Act) was enacted almost 100 years ago, but it is even older than this. It is based on, and almost identical to, the Sale of Goods Act 1893 (UK), which was enacted well before many of the advancements which are now commonplace in our personal and business environments. For example, it was before the internet made it possible for transactions to be made electronically. The continued application of many of the rules creates a time-warp in this area of the law. ${ }^{18}$ As Sutton notes: ${ }^{19}$

Its provisions reflect the promises made in the relatively simple types of contracts commonly in use in that period. In order to adapt it to the much more complicated contracts which are customarily in use today as a necessary concomitant of the advances in technology and changes in the way in which business is carried on in the $20^{\text {th }}$ Century, the provisions of the Act must be treated as general principles for ascertaining the common intention of the parties as to their mutual promises and their consequences, which are to be applied by analogy in cases arising out of contracts not within the contemplation of the drafter in 1893.

At the very least the Act is in dire need of an update, a fact recognised by the New Zealand Law Commission in 1993. ${ }^{20}$ However, whereas the Law Commission proposed to amend the Contractual Remedies Act 1979 to cover sale of goods contracts, I argue that the remedies provisions of the CISG should be adopted so as to remove the current, unnecessary distinction between international and domestic sales of goods.

\section{The rules no longer engender certainty}

As a result of the acceptance in 1962 of the category of intermediate terms, the courts are becoming reluctant to classify contractual terms as conditions. ${ }^{21}$ An element of uncertainty has crept into the law with some judges expressing uneasiness in following precedent that leads to unjust results. In order to demonstrate this, an analysis of the way in which courts distinguish between conditions, warranties and intermediate terms is necessary.

18 See the language used in Sale of Goods Act 1908, s 35.

19 Kenneth Sutton Sales and Consumer Law (4 ed, LBC Information Services, Sydney, 1995) 4.

20 New Zealand Law Commission Contract Statutes Review (NZLC R25, Wellington, 1993) 8.

21 Hong Kong Fir Shipping, above n 10. 
In the first place, judicial classification of a term as a warranty is rare, ${ }^{22}$ because it is unlikely that the parties' intentions would be that no breach of the term would justify the innocent party in terminating the contract, no matter how serious the consequences of the breach.

As between conditions and intermediate terms, two issues of policy arise. The classification of terms as conditions favours commercial certainty since once a term has been classified as a condition, it will enable innocent parties in similar future cases to know that they are able to terminate the contract. ${ }^{23}$ The classification of terms as intermediate terms promotes justice as between the parties because it restricts the right to terminate the contract to contracts where the breach results in serious prejudice to the innocent party. In the words of Roskill LJ (as he then was): $:^{24}$

[C]ontracts are made to be performed and not to be avoided according to the whims of market fluctuation and where there is a free choice between two possible constructions I think the court should tend to prefer that construction which will ensure performance and not encourage avoidance of contractual obligations.

As a result of this attitude, the courts have begun to follow "the [more] modern approach of not being overready to construe terms as conditions unless the contract clearly requires the court to do so." 25 Therefore, it is likely that a term will be classified as an intermediate term unless either the parties have expressly stipulated the consequences of a breach of the term in advance, or the Act or prior case law prescribes the status of the term.

In addition, Lord Wilberforce has said that precedent in this area is "excessively technical and due for fresh examination in this House."26 While such an examination is yet to take place, his

22 Treitel Contract, above n 13, 797; Jack Beatson Anson's Law of Contract (28 ed, Oxford University Press, Oxford, 2002) 138-139; Hugh Beale (ed) Chitty on Contracts (29 ed, Sweet \& Maxwell, London, 2004) 722 [Beale Chitty on Contracts].

23 See Maredelanto Compania Naviera SA v Bergbau-Handel mbH (The Mihalis Angelos) [1971] QB 164, 205 (CA) Megaw LJ. There is certainly something to be said for the law of contract promoting certainty or predictability. But this is particularly so in sale of goods contracts which, because they are frequently part of a "chain" of contracts, or concern perishable goods, require the parties' rights to be easily ascertainable in case of breach.

24 The Hansa Nord, above n 16, 755 Roskill LJ.

25 Bunge Corporation of New York v Tradax Export SA [1981] 2 All ER 513, 551 (HL) Lord Roskill.

26 Reardon Smith Line Ltd v Yngvar Hansen-Tangen [1976] 3 All ER 570, 576 (HL) Lord Wilberforce. An example of an "excessively technical" breach is the case of Arcos Ltd v E A Ronaasen \& Son [1933] AC 470 (HL). The delivery of timber $9 / 16$ of an inch thick instead of $1 / 2$ an inch thick as specified in the contract was held to justify rejection of the timber even though the thickness made no difference to the buyer's intended use. It seems probable that the real reason for the rejection was that the market price of timber had fallen: see Treitel Contract, above n 13, 793-794; Beale Remedies, above n 7, 36-37. 
Lordship's statement indicates that the force of prior judicial classification of particular terms as conditions is waning in favour of the case-by-case approach propounded by Lord Roskill.

Consequently, the policy consideration of certainty has been undermined. The "back up" category of intermediate terms has given judges "a considerable degree of flexibility in its construction of stipulations in contracts for the sale of goods." ${ }^{27}$ It is no longer clear that the courts will regard themselves as being bound by a prior judicial classification. Justice in the particular case has overtaken certainty as the dominant policy factor to be considered by the courts in classification.

This article does not contend that the displacement of certainty as the primary aim of the law in this area is a wrong step. On the contrary, the courts are right to regard doing justice as between the parties in the particular circumstances of each case as a more important concern of the law than promoting certainty. This is especially so if the corollary of certainty is doing injustice by permitting technical breaches and bad faith termination.

Nonetheless, the unsatisfactory state of the law, with the words of the statute and the approach of the courts at cross-purposes, gives impetus to the argument that the time is ripe for Parliament to adopt the CISG's rules relating to remedies for breaches of sale of goods contracts as the domestic law of New Zealand. This would have the desirable result that no difference of approach would be required for domestic or international sales of goods.

\section{TERMINATION FOR BREACH IN THE CISG}

The thesis of this article is that there is no reason to distinguish between international and domestic sales of goods at the level of remedies for breach. Nonetheless, sale of goods contracts are a sub-category of contracts in general. The adoption of a law which clashes on a fundamental level with general principles of contract law in New Zealand would be worse than retaining the current distinction between domestic and international sale of goods contracts. In consideration of this, the general principles underlying the CISG will be outlined and analysed in order to identify and assess potential problems in adopting the CISG's remedies provisions as the domestic law of New Zealand. Once this comparison has been made, the preconditions for termination of the contract by an innocent party for breach under the CISG can be analysed.

\section{A General Principles of the CISG}

1 Party autonomy

Article 6 of the CISG provides that the parties may exclude its application or, subject to article $12,{ }^{28}$ derogate from or vary the effect of any of its provisions. In this way "the Convention ...

27 Sutton, above n 19, 188.

28 Article 12 of the CISG permits a contracting State to declare a reservation preserving its domestic requirements as to contractual form. This is the only restriction on freedom of contract. 
responds to the power of agreement. ... [It] does not interfere with the freedom of sellers and buyers to shape the terms of their transactions."29 This means that "the Convention applies only to the extent that no contrary intention of the parties can be established." 30

The CISG therefore acts as a backdrop against which the parties may contract. It supplements the terms of sale where the parties omit to consider a particular situation and provides the means by which the contract is interpreted. But it does not restrain the parties' right to decide their own contractual terms and to derogate from the provisions of the CISG. For example, if the parties wish to provide for a less strict avoidance provision they may do so by setting out the circumstances in which avoidance of the contract may take place.

The New Zealand position is the same. The: ${ }^{31}$

[B]asic philosophy [of the Sale of Goods Act 1908] is that, subject to any limitations imposed by statute or public policy, the parties have complete freedom of choice not only as to what each will promise to do but also as to what each will accept as the consequences of performance or non-performance of those promises.

The public policy limitations on freedom of contract include the protection of consumers, which are given effect by the enacting of consumer protection legislation. Since sales of goods for personal, family or household use are excluded from the CISG's sphere of application, ${ }^{32}$ the adoption of the CISG remedies provisions domestically need not affect the continued application of the Consumer Guarantees Act 1993 to consumer sales of goods.

\section{Pacta sunt servanda}

As the New Zealand Law Commission wrote in its report on New Zealand's acceptance of the CISG, the CISG responds to "the distances involved [in international trade], the costs of transportation, the involvement of intermediaries, and the long term that many [contracts] are to operate". ${ }^{33}$ The preamble to the CISG states that it "contribute[s] to the removal of legal barriers in international trade and promote[s] the development of international trade". ${ }^{34}$ In light of these

29 John O Honnold Uniform Law for International Sales under the 1980 United Nations Convention (3 ed, Kluwer Law International, The Hague, 1999) 77-87.

30 Michael Joachim Bonell Bianca-Bonell Commentary on the International Sales Law (Giuffrè, Milan, 1987) 51-64.

31 Sutton, above n 19, 4. See Christopher Hill Ltd v Ashington Piggeries Ltd [1972] AC 441, 501 (HL) Lord Diplock.

32 CISG, above n 1, art 2(a).

33 New Zealand Law Commission The United Nations Convention on Contracts for the International Sale of Goods: New Zealand's Proposed Acceptance (NZLC R23, Wellington, 1992) para 23.

34 CISG, above n 1, preamble. 
considerations, one of the general principles of the CISG is "the preservation of the contract notwithstanding default or other non-compliance." ${ }^{35}$ In other words, pacta sunt servanda. This principle requires that, except in the cases required by the CISG, the contract be kept on foot, and be given effect to, to the greatest extent possible. In turn, it requires that provisions providing for termination of the contract be construed strictly.

Coupled with this general principle is a duty that both parties preserve goods in their possession belonging to the other party. According to the Explanatory Note to the CISG prepared by the UNCITRAL Secretariat: ${ }^{36}$

[S] uch a duty is of even greater importance in an international sale of goods where the other party is from a foreign country and may not have agents in the country where the goods are located. Under certain circumstances the party in possession of the goods may sell them, or may even be required to sell them. A party selling the goods has the right to retain out of the proceeds of sale an amount equal to the reasonable expenses of preserving the goods and of selling them and must account to the other party for the balance.

Such measures are provided for in consideration of the costs, risks and distances involved in international trade, but may also be said to arise from the duty in the interpretation of the CISG to observe good faith in international trade, imposed by article 7(1).

That such international considerations are at the forefront of the CISG's drafting is not a reason to reject its application domestically. In shipping goods from Whangarei to Invercargill, a seller will face not insignificant transportation and communication costs. This is especially the case with the rising cost of using fossil fuels.

However, the contrary position is taken in the Sale of Goods Act 1908. Section 38 provides that "[u]nless otherwise agreed, where goods are delivered to the buyer, and he refuses to accept them, having the right so to do, he is not bound to return them to the seller, but it is sufficient if he intimates to the seller that he refuses to accept them." In the author's opinion, such a rule ignores the reality of modern trade. Even in a domestic context, and as outlined in more detail below, ${ }^{37}$ there are still significant distances, risks and costs involved. The more collaborative CISG rule better reflects the impact of these costs, risks and distances. Therefore, even though this difference exists, it should not prevent the adoption of the CISG remedies provisions as the domestic law of New Zealand.

35 New Zealand Law Commission, above n 33, para 23.

36 Explanatory Note, above n 3, Introduction, para 32

37 See Part V Trade in New Zealand. 
In this regard, it is instructive to consider the position in New Zealand concerning contracts to which the Contractual Remedies Act 1979 applies. Section 7 provides for cancellation in the case of breach in two circumstances, doing away with the condition-warranty distinction. ${ }^{38}$ The first circumstance is where the parties agree that performance of the term of the contract is essential. ${ }^{39}$ This reflects the common law rule, which still applies to sale of goods contracts, that where the parties expressly stipulate what the consequences of a breach shall be, the courts will give this stipulation its intended effect. ${ }^{40}$ The second circumstance is where the effect of the breach either substantially reduces the benefit of the contract, ${ }^{41}$ substantially increases the burden of the contract, ${ }^{42}$ or makes the benefit or burden substantially different from that contracted for. ${ }^{43} \mathrm{~A}$ contract will accordingly remain on foot unless the effects of the breach are substantial, or if the parties expressly provide for cancellation in case of any breach of the term. It is in many ways the reverse of the position under the Sale of Goods Act 1908.

Therefore, the adoption of the CISG remedies provisions in relation to sale of goods contracts would actually have the effect of bringing closer together the divergent principles of the Contractual Remedies Act 1979 and the Act. It would increase the extent to which pacta sunt servanda is a principle of New Zealand contract law.

\section{Good faith $^{44}$}

Article 7(1) of the CISG provides that "[i]n the interpretation of this Convention, regard is to be had to its international character and to the need to promote uniformity in its application and the observance of good faith in international trade." A literal interpretation of this provision reveals only a requirement of good faith in the interpretation of the CISG. However, some authors go further and argue that the considerations of international trade which underpin the CISG lead to the conclusion that article 7 requires the observance of good faith by the parties during the course of the

38 Francis Dawson and David W McLauchlan The Contractual Remedies Act 1979 (Sweet \& Maxwell Ltd, Auckland, 1981) 5.

39 Contractual Remedies Act 1979, s 7(4)(a).

40 Dawson and McLauchlan, above n 38, 96.

41 Contractual Remedies Act 1979, s 7(4)(b)(i).

42 Contractual Remedies Act 1979, s 7(4)(b)(ii).

43 Contractual Remedies Act 1979, s 7(4)(b)(iii).

44 A helpful working definition of the duty of good faith is "an expectation and obligation to act honestly and fairly in the performance of one's contractual duties. A certain amount of reasonableness is expected from the contracting parties." See Paul J Powers "Defining the Undefinable: Good Faith and the United Nations Convention on Contracts for the International Sale of Goods" (1999) 18 J L \& Com 333, 334. 
contract. ${ }^{45}$ The duty to mitigate losses and to preserve goods belonging to the other party are said to be particular expressions of the general requirement of good faith. ${ }^{46}$

It is trite to say that there is no principle of good faith of general application in the contract law of New Zealand. However, the concept is used frequently as a touchstone in dealing with third parties in the law of obligations generally, and relevantly for the argument here, as a synonym for honesty in sections 25 and 48 of the Sale of Goods Act $1908 .{ }^{47}$ Further, there are signs that an underlying doctrine of good faith is becoming less and less objectionable to the common law. In Livingstone $v$ Roskilly Thomas J opined that a number of contract doctrines could be explained as founded on a latent premise of good faith, including: ${ }^{48}$

... the rule which invalidates a penalty provision; the rule providing for relief against forfeiture; rules providing for the importation of implied terms and the severance of ineffective terms to give a contract

business efficacy and rules of construction such as the contra proferentem rule.

The inclusion of good faith in the CISG should not be an obstacle to the adoption of its remedies provisions as the domestic law of New Zealand. This is because, first, on the narrow, more literal view of article 7(1), good faith is a directory norm to be used in the interpretation of the provisions of the CISG. Secondly, even on the broader approach which sees good faith as a specific obligation on parties to contracts which come within the scope of the CISG, it is an obligation which better reflects the co-operation necessary between parties selling and carrying goods over large distances with a significant amount of risk of loss. Since the proposal for reform articulated here would perpetuate the separation of sale of goods contracts from contracts generally in respect of the remedies available for breach, the application of good faith to sale of goods contracts in this way will not affect that broader category. It will simply become an addition to the list espoused in Livingstone $v$ Roskilly of contract doctrines based on good faith.

45 See Schlechtriem Commentary, above n 4, 63; Phanash Koneru "The International Interpretation of the UN Convention on Contracts for the International Sale of Goods: An Approach Based on General Principles" (1997) 6 MJGT 105, 139-141; Amy H Kastely "Unification and Community: A Rhetorical Analysis of the United Nations Sales Convention" (1988) 8 NJILB 574, 596-597.

46 Kastely, above n 45, 596.

47 Sale of Goods Act 1908, s 2(2) states that "[a] thing is deemed to be done in good faith within the meaning of this Act when it is in fact done honestly, whether it is done negligently or not."

48 Livingstone v Roskilly [1992] 3 NZLR 230, 238 (CA) Thomas J. See also Interfoto Picture Library Ltd v Stiletto Visual Programmes Ltd [1989] QB 433, 439 (CA) Bingham LJ. See generally Burrows, Finn and Todd, above n 9, 20 . 


\section{Reasonableness}

One element of the requirement of good faith, or at least a related concept on the same level as good faith, ${ }^{49}$ is that the parties must act reasonably in their dealings. Reasonableness is a ubiquitous concept in the CISG. It is used as a threshold or touchstone in no fewer than 35 places in the CISG text.

From this universal presence, Professor Schlechtriem concludes that reasonableness is a fundamental principle of the CISG. ${ }^{50}$ Such a principle stands in conflict with what could be regarded as a more important consideration; that of certainty and security in international trade. Nonetheless, it is a necessary trade-off in an international instrument which is intended to have a broad, general and long-term application to international sales. It may be an uncertain concept, but any uncertainty is displaced by the parties' ability to prescribe more certain contractual terms specific to their own particular circumstances. ${ }^{51}$

Reasonableness is not a concept unknown to the law in New Zealand and in particular to the area of the sale of goods. The Sale of Goods Act 1908 makes numerous references to the concept of reasonableness. ${ }^{52}$ Therefore, while it is true that the use of a concept such as reasonableness engenders some uncertainty in the law, there is no difference in this respect between the CISG and the current sale of goods regime.

As a result of comparing these general principles it can be seen that, with the exception of good faith, the general principles underlying the CISG are not dissimilar from the underlying principles of the Act. The crucial principles of party autonomy, pacta sunt servanda and reasonableness are as enshrined in the CISG as they are in New Zealand law already. This congruity is important when it comes to contemplating the reform of the domestic sale of goods remedies to bring it into line with the international scheme. No real objection can be made on this score.

Whether the rules provided by the CISG can be adopted in terms of their substantive difference to the current New Zealand law is now considered.

49 See Guillaume Weiszberg Le "Raisonnable" en Droit du Commerce International [On "Reasonableness" in International Commercial Law] (Doctoral Thesis, l'Université Panthéon-Assas (Paris II), 7 November 2003) fn 598 ("il en constituerait un principe général du même rang que celui de la bonne foi" / "it represents a principle on the same level as good faith") available at Pace Law School CISG Database < http://www.cisg.law.pace.edu> (last accessed 3 August 2006).

50 Schlechtriem Commentary, above n 4, 67.

51 New Zealand Law Commission, above n 33, para 97.

52 See for example section 16 of the Sale of Goods Act 1908 which requires that goods sold for a particular purpose must be reasonably fit for that purpose, and sections 20,31(3), 31(5), 37, 39 and 57 which use "reasonable time" as a criterion for gauging performance. 


\section{B Avoidance of the Contract}

Avoidance of the contract is the CISG's equivalent of termination of the contract for breach. ${ }^{53}$ It releases both parties from any unperformed obligations, subject to damages that may be due, ${ }^{54}$ although any contractual provisions relating to the resolution of disputes or concerning the obligations of the parties on avoidance survive. ${ }^{55}$

In some circumstances avoidance may lead to different consequences under the CISG than under the common law. Article 81(2) of the CISG provides that:

[a] party who has performed the contract either wholly or in part may claim restitution from the other party of whatever the first party has supplied or paid under the contract. If both parties are bound to make restitution, they must do so concurrently.

In contrast, the common law does not always provide a complete restitutionary remedy on termination of a contract. ${ }^{56}$ In such cases restitution will only be permitted for a total failure of basis. ${ }^{57}$ If the basis has not wholly failed (such as where only some of the goods delivered were defective), then a restitutionary remedy will not be available,${ }^{58}$ except where the contract is divisible and the divisible part of the contract has wholly failed. ${ }^{59}$ Since this rule leads to injustice in some cases, ${ }^{60}$ its rejection in a sale of goods context may well be welcomed. ${ }^{61}$

53 Schlechtriem, Commentary, above n 4, 415.

54 CISG, above n 1, art 81(1).

55 CISG, above n 1, art 81(1).

56 The provisions relating to post-termination relief such as restitution found in section 9 of the Contractual Remedies Act 1979 do not apply to sale of goods contracts: see Contractual Remedies Act 1979, s 15(d). As a result, in sale of goods cases, a plaintiff must seek restoration of benefits on the ground of failure of basis. See also Ross B Grantham and Charles E F Rickett Enrichment and Restitution in New Zealand (Hart Publishing, Portland, 2000) 169-170.

57 See Fibrosa Spolka Akcyjna v Fairbairn Lawson Combe Barbour [1943] AC 32 (HL) [Fibrosa]; Stocznia Gdanska SA v Latvian Shipping Co [1998] 1 WLR 574 (HL) [Stocznia].

58 Fibrosa, above n 57; Stocznia, above n 57.

59 Goss v Chilcott [1996] 3 NZLR 385, 391 (PC) Lord Goff of Chieveley; A G Guest (ed) Benjamin's Sale of Goods (6 ed, Sweet \& Maxwell, London, 2002) 949.

60 See Grantham and Rickett, above n 56, 157-164; Andrew Burrows The Law of Restitution (2 ed, Butterworths LexisNexis, London, 2002) 333-336.

61 Professor Burrows in particular has argued that the requirement that the failure be total should be removed in favour of restitution in cases of partial failure: Burrows, above n 60, 333-336. 
However, in order to make avoidance consistent with the underlying principle of pacta sunt servanda, it is construed as a "last resort" remedy. ${ }^{62}$ As a result, the CISG ignores the common law condition-warranty distinction, favouring an approach which takes into account the actual consequences caused by the breach.

Both the buyer and the seller may declare the contract avoided in two main situations: first, when a fundamental breach of contract occurs; and secondly, when one party has extended the time for contractual performance, but the other party still fails to perform in time.

\section{Fundamental breach}

The first situation in which a party may avoid the contract is if the breach of contract amounts to a fundamental breach. ${ }^{63}$ The core substance of a fundamental breach has been described as the foreseeable substantial deprivation of contractual expectations. ${ }^{64}$ Article 25 of the CISG defines a fundamental breach as one:

Result[ing] in such detriment to the other party as substantially to deprive him of what he is entitled to expect under the contract, unless the party in breach did not foresee and a reasonable person of the same kind in the same circumstances would not have foreseen such a result.

This article contains two distinct limbs. The first limb is the requirement of substantial deprivation of the non-breaching party's expectation interest. The second limb requires that the substantial deprivation be foreseeable.

(a) Substantial deprivation

62 Robert A Hillman "Applying the United Nations Convention on Contracts for the International Sale of Goods: The Elusive Goal of Uniformity" in Cornell International Law Journal Cornell Review of the Convention on Contracts for the International Sale of Goods 1995 (Aspen Publishers, New York, 1996) 21; Clemens Pauly "The Concept of Fundamental Breach as an International Principle to Create Uniformity of Commercial Law" (2000) 19 J L \& Com 221, 225. See also Bundesgerichtshof (German Supreme Court) 3 April 1996 VIII ZR 51/95 <http:/www.cisg-online.ch> (last accessed 3 August 2006).

63 CISG, above n 1, arts 49(1)(a) and 64(1)(a).

64 Chengwei Liu "The Concept of Fundamental Breach: Perspectives from the CISG, UNIDROIT Principles and PECL and Case Law [2nd edition: Case annotated update (May 2005)]" Pace Law School CISG Database $<$ http://www.cisg.law.pace.edu $>$ (last accessed 3 August 2006). 
The CISG does not indicate what will amount to substantial deprivation. ${ }^{65}$ Since the consequences of fundamental breach are the most serious of all the available remedies, it makes sense that the requisite threshold is also high. As noted above, ${ }^{66}$ this is a last resort remedy. The substantial deprivation must reach such a high threshold that the non-breaching party cannot be expected to continue to perform its obligations under the contract. Case law bears this proposition out. In a 1991 decision, the German Oberlandesgericht (Court of Appeal) stated: "[a] breach of contract is fundamental when the purpose of the contract is endangered so seriously that, for the concerned party to the contract, interest in the fulfilment of the contract ceases to exist as a consequence of the breach of the contract." 67

Whether the threshold is reached is determined by reference to the large number of considerations which make up the expectation interest of the non-breaching party. All the circumstances of the case come into play in determining whether a breach amounts to a fundamental breach. These considerations will come from, and be assessed in light of, the language of the contract as well as the circumstances surrounding the relationship of the parties. The economic loss of the non-breaching party is likely to be the most prominent of these considerations. But, in addition, the question can encompass the consideration of factors such as loss of the non-breaching party's reputation, subject to these considerations being foreseeable to a reasonable person of the same kind and in the same circumstances as the breaching party.

One author even argues that the determination of fundamental breach requires a "remedyoriented approach". ${ }^{68}$ Such an approach would take into account all the circumstances in a global assessment of the substantiality of the detriment, and also consider (in accordance with the last

65 The Secretariat Commentary tends to suggest that the drafters intended the "substantial deprivation" to be determined almost solely by reference to the economic loss caused by the breach, on a case by case basis. Commentary by the UNCITRAL Secretariat on the United Nations Convention on Contracts for the International Sale of Goods, Pace Law School CISG Database <http://cisg.law.pace.edu $>$ (last accessed 3 August 2006) art 23, para 3. In the author's opinion, however, the Secretariat Commentary is of little help in respect of article 25 because the final form of article 25 differs significantly from the equivalent article in the 1978 Draft Convention in respect of which the Commentary was prepared. The concept of expectation interest, for example, is not present in the 1978 Draft.

66 See Part III A 2 Pacta sunt servanda.

67 Oberlandesgericht (German Court of Appeal), Frankfurt, 17 September 1991 (5U 164/90), Pace Law School CISG Database < http://www.cisg.law.pace.edu > (last accessed 3 August 2006). An English translation can be found at (1993) 12 J L \& Com 261

68 Robert Koch "The Concept of Fundamental Breach under the United Nations Convention on Contracts for the International Sale of Goods (CISG)" in Pace Law School (ed) Review of Convention on Contracts for the International Sale of Goods (CISG) 1998 (Kluwer Law International, The Hague, 1999) 177, 350. 
resort principle) whether the interests of the non-breaching party are sufficiently satisfied by damages. If so, then there is no fundamental breach. If not, then there is a fundamental breach. ${ }^{69}$

Thus, the importance of the breached term is merely a factor to be considered, along with the actual consequences of the breach, when determining whether a breach of contract is fundamental. In this way, the question of fundamental breach in the CISG is similar to the determination of intermediate terms in New Zealand law, but with a wider array of considerations to be taken into account by the decision-maker.

(b) Foreseeability

Once the non-breaching party has established that the breach resulted in such detriment as substantially to deprive it of what it expected to receive under the contract, the breaching party may prevent the avoidance of the contract by demonstrating that it did not foresee such a result, and that a reasonable person of the same kind and in the same circumstances would not have foreseen such a result.

This element acts as a filter. ${ }^{70}$ It has the result that where detriment shown to be substantial comes as a "surprise", ${ }^{71}$ the substantial detriment will not lead to a finding of fundamental breach because such detriment was not foreseeable. The preponderance of authority on the subject shows that the burden of proof for the foreseeability element is on the party in breach. ${ }^{72}$ The burden shifts once the non-breaching party has proved its detriment and shown it to be substantial.

(c) Summary

In summary, it can be said that the concept of fundamental breach in the CISG is very wide in terms of the circumstances that can be relevant towards determining whether a breach is fundamental in any given case. Yet, because of the general principle of pacta sunt servanda, it requires a high threshold to be met before it is applied. Such a position avoids the sometimes unjust results of the New Zealand condition-warranty distinction where parties are able to take advantage of minimal or technical breaches as a way of extricating themselves from contracts that have subsequently become bad bargains.

69 Koch, above n 68,350

70 Leonardo Graffi "Case Law on the Concept of 'Fundamental Breach' in the Vienna Sales Convention" (2003) 3 IBLJ 338.

71 Liu, above n 64.

72 The main reason for this is the maxim onus probandi incumbit ei qui dicit, meaning "the onus of proof lies with the party who substantially asserts the affirmative of the issue". See Liu, above n 64; Graffi, above $n$ 70; Koch, above n 68, 288. 
Further, while it may appear that this rule does not bring with it the same supposed legal certainty that those who favour the condition-warranty distinction would champion, ${ }^{73}$ the rule does nonetheless have an element of certainty to recommend it. The parties may not know beyond doubt until judicial decision that a breach does in fact reach the threshold of foreseeable substantial deprivation, justifying avoidance of the contract. However, for two reasons, it cannot be said that certainty is thrown out the window.

First, the rule does not prevent the parties from "mak[ing] it clear in the contract that particular obligations or methods of performing them are of essential importance for the promisee." 74 In fact, the general principles of the CISG specifically encourage it. Doing so will have two results. First, such a contractual term will have the same effect as a "condition" of the contract (as that word is used in the New Zealand terminology); and secondly, "there will be no room for a reduction in its importance using the foreseeability limitation." 75

Secondly, certainty is promoted by the high threshold which must be reached before avoidance of the contract is justified. Non-breaching parties wondering whether they can avoid the contract or not can be sure that the contract remains on foot unless the harm caused leaves them no option but to avoid. Since it is described as a last-resort remedy, this will be the case where the non-breaching party has no reasonable option open to it other than to avoid the contract.

The CISG's rules relating to the preconditions of avoidance of the contract better reflect the reality of modern trade than the New Zealand rules. For example, if a seller delivers goods to a buyer on the other side of the world, and the buyer avoids the contract, the seller will need to take back the goods supplied, which "necessarily involves risk of damage or loss and expenses such as transportation and storage". ${ }^{76}$ This factor alone demonstrates the necessity of keeping the contract on foot to the greatest extent possible. The economic and trade situation in New Zealand, with the not insignificant distances and costs involved, justifies the same approach to termination of the contract to be taken here.

\section{Additional period of time for performance}

The CISG, in accordance with the general principle of pacta sunt servanda,${ }^{77}$ also includes the mechanism of extending the contractual period for performance on the initial breach of a contract. ${ }^{78}$

73 Guest, above n 59, 965-6; Barry Nicholas "The Vienna Convention on International Sales Law" (1989) 105 LQR 201, 242-243.

74 Schlechtriem Commentary, above n 4, 178.

75 Schlechtriem Commentary, above n 4, 178

76 Koch, above n 68, 186.

77 Hillman, above n 62, 21; Pauly, above n 62, 225.

78 CISG, above n 1, arts 47(1) and 63(1). 
This provides the second situation in which either party may declare the contract avoided. If the non-breaching party fixes an additional period of time for the breaching party to perform, and either that time expires, or the breaching party states that it will not perform within that time, the nonbreaching party may avoid the contract. ${ }^{79}$ An extension of time has the effect of postponing the date for performance, thereby keeping the contract on foot, and after that postponed date has passed, turning any breach, whether or not fundamental, into a breach that justifies avoidance of the contract (as long as, in the case of non-conforming delivery, notice of avoidance is given within a reasonable time). ${ }^{80}$

This rule may not be entirely consistent with the general principle of keeping contracts on foot since cases can be envisaged where a minor breach is still minor even after the expiry of the additional period of time. Nonetheless, a justification for this rule is that the breaching party has been given the opportunity to remedy the initial breach of contract and has either refused or failed to do so in time. If it has refused, the situation is similar to renunciation of the contract at common law in that the words or conduct of the breaching party make it clear that it will never perform the contract. ${ }^{81}$ If it has failed to do so in the requisite time the further delay is likely to make the breach more serious, justifying avoidance on fundamental breach grounds. In cases where the delay has not exacerbated the breach, avoidance is justified as allowing the non-breaching party to obtain a certain legal position.

The ability of a non-breaching party to fix an additional period of time for performance is a useful self-help remedy. It is typically used by the buyer in the case of the seller's non-delivery ${ }^{82}$ or non-conforming delivery, ${ }^{83}$ and by the seller in the case of the buyer's non-payment or refusal to take delivery of the goods. ${ }^{84}$ It is not mandatory and therefore need not be used if the breach of contract already amounts to a fundamental breach justifying avoidance of the contract. ${ }^{85}$ There is no reason why this remedy should not be adopted as part of New Zealand's domestic sale of goods law.

79 CISG, above n 1, arts 45(1)(b) and 64(1)(b).

80 CISG, above n 1, arts 45(1)(b), 45(2)(b)(ii), 64(1)(b) and 64(2)(b)(ii).

82 CISG, above n 1, art 45(1)(b).

4 CISG, above n 1, art 64(1)(b). 


\section{OTHER REMEDIES AVAILABLE}

Having considered termination and avoidance of the contract, and concluded that the CISG's avoidance rules better reflect international trade considerations, this section analyses and compares the other remedies available in New Zealand and under the CISG for breach of contract.

\section{A Other Remedies in the Sale of Goods Act 1908}

Part V of the Sale of Goods Act 1908 deals with remedies. The provisions are separated into remedies of the seller (sections 50-51) and remedies of the buyer (sections 52-54). This division is important, because while the right to damages is available to both parties, other remedies are specific to the buyer or seller. For example, an unpaid seller may exercise a lien over goods of which he or she is still in possession to ensure payment, notwithstanding that the property in the goods may have passed to the buyer. ${ }^{86}$ This remedy is dependent on the breach of the buyer's duty to pay the price of the goods, ${ }^{87}$ which is a condition. ${ }^{88}$ In contrast, no reciprocal buyer's lien exists over delivered goods which are rejected as being defective in order to secure the delivery of conforming goods.

Another example is the seller's right to bring an action for the price of the goods in cases where the property in the goods has passed to the buyer, but the buyer has not paid the price. ${ }^{89}$ This is important because it is an action in debt, not in damages, ${ }^{90}$ and so is not subject to the rules relating to recovery of damages including proof, remoteness, and mitigation of loss. ${ }^{91}$

Specific performance of the contract is another remedy available to a buyer. ${ }^{92}$ It is discretionary and will not be awarded if damages are an adequate remedy. Damages will be an adequate remedy generally in cases where replacement goods are available in the market, so specific performance is normally reserved for cases of specific or ascertained goods. ${ }^{93}$

While the condition-warranty distinction is important in determining the rights of the innocent party concerning termination, in most cases a breach will lead to a claim for damages to compensate

86 Sale of Goods Act 1908, s 41(1)(a).

87 Sale of Goods Act 1908, s 29.

88 Sale of Goods Act 1908, s 30.

89 Sale of Goods Act 1908, s 50.

90 Guest, above n 59, 818; Beale Chitty on Contracts, above n 22, 1428 and 1462.

91 White and Carter (Councils) Ltd v McGregor [1962] AC 413 (HL); Guest, above n 59, 818; Beale Chitty on Contracts, above n 22, 1428 .

92 Sale of Goods Act 1908, s 53(1).

93 See Thomas Borthwick \& Sons (Australasia) Ltd v South Otago Freezing Co Ltd [1978] 1 NZLR 538 (CA); Butler $v$ Countrywide Finance Ltd [1993] 3 NZLR 623 (HC) Hammond J. 
the innocent party for the breach that has occurred. ${ }^{94}$ Damages for a breach of contract are recoverable as of right. ${ }^{95}$ The common law principles that have developed concerning the measure of damages available to an innocent party as applied in sale of goods law are easily stated.

The purpose of damages for breach of contract, as expressed in the leading case, Robinson $v$ Harman, is to put the plaintiff, so far as money can, back in the position they would have been in had the contract been performed. ${ }^{96}$

The Act expresses the measure of damages which will achieve this as the estimated loss directly and naturally resulting, in the ordinary course of events, from the breach of contract. ${ }^{97}$ Sutton ${ }^{98}$ treats these words as simply a statutory expression of the traditional common law rule of remoteness of damage found in Hadley $v$ Baxendale, ${ }^{99}$ Victoria Laundry (Windsor) Ltd v Newman Industries Ltd ${ }^{100}$ and Koufos $v$ C Czarkinow Ltd (The Heron II). ${ }^{101}$ Further, section 55 of the Act states that "[n]othing in this Act shall affect the right of the buyer or the seller to recover ... special damages in any case where by law ... special damages may be recoverable." This provision permits a nonbreaching party to recover damages which may not have resulted directly and naturally but which were nevertheless foreseeable to the breaching party because of its knowledge of special circumstances. ${ }^{102}$

\section{B Other Remedies in the CISG}

The remedies available to both parties can be classified into four categories: first, specific performance; secondly, avoidance of the contract; thirdly, fixing an additional period of time for performance; and fourthly, damages. Apart from the remedy of avoidance of the contract, these remedies may be claimed for any breach of contract. ${ }^{103}$ In addition to these remedies, the buyer

94 Burrows, Finn and Todd, above n 9, 742-743.

95 Treitel Contract, above n 13, 926; Beale Chitty on Contracts, above n 22, 1427.

96 Robinson v Harman (1848) 1 Exch 850, 855 Parke B.

97 Sale of Goods Act 1908, ss 51(2), 52(2) and 54(2).

98 Sutton, above n 19, 661-669; see also Guest, above n 59, 844-845.

99 Hadley $v$ Baxendale (1854) 9 Exch 341.

100 Victoria Laundry (Windsor) Ltd v Newman Industries Ltd [1949] 2 KB 528.

101 Koufos v C Czarkinow Ltd (The Heron II) [1969] 1 AC 350 (HL).

102 H Parsons (Livestock) Ltd v Uttley Ingham \& Co Ltd [1978] QB 791, 807 (CA) Scarman LJ. See also Guest, above n 59, 847; Andrew Borrowdale (ed) Butterworths Commercial Law in New Zealand (4 ed, Butterworths, Wellington, 2000) 305.

103 CISG, above n 1, arts 45(1) and 61(1); Albert H Kritzer Guide to Practical Applications of the United Nations Convention on Contracts for the International Sale of Goods (Kluwer Law and Taxation Publishers, Boston, 1989) 18. 
may exercise the remedy of unilaterally reducing the price in the case of the seller delivering nonconforming goods. ${ }^{104}$

\section{Specific performance}

In the CISG, specific performance is the primary remedy envisaged for a breach of contract. ${ }^{105}$ Article 46(1) provides that "[t]he buyer may require performance by the seller of his obligations unless the buyer has resorted to a remedy which is inconsistent with this requirement." Article 62(1) provides that "[t]he seller may require the buyer to pay the price, take delivery or perform his other obligations, unless the seller has resorted to a remedy which is inconsistent with this requirement."

The substance of these articles is that either party may force the other party to perform any outstanding contractual obligations. This remedy is subject to article 28 which provides that a court is not bound to enter judgment for specific performance unless the court would do so under its own law in respect of similar contracts of sale not governed by the CISG.

As a result, specific performance as a remedy under the CISG is not any different in practice than it is in New Zealand under the Act. That is because no New Zealand court would be required to make an order for specific performance if it would not do so in the same circumstances under the Act. Therefore, the New Zealand legislature has a choice. It may accept the primacy of specific performance as a remedy in the CISG and adopt it in this way. Or it may prefer to continue with damages as the primary remedy for breach of contract, subject to the current rule relating to when specific performance will be ordered. This will not disrupt the general principles of the CISG since the drafters have already provided for this possibility in article 28.

\section{Damages}

Damages are available as of right and may be claimed in addition to the exercise of any other remedy under the CISG. "Article 74 provides a basic rule defining the general extent of the obligation to pay damages for all cases in which the Convention provides for such an obligation."106 It states:

Damages for breach of contract by one party consist of a sum equal to the loss, including loss of profit, suffered by the other party as a consequence of the breach. Such damages may not exceed the loss which the party in breach foresaw or ought to have foreseen at the time of the conclusion of the contract, in the light of the facts and matters of which he then knew or ought to have known, as a possible consequence of the breach of contract.

104 CISG, above n 1 , art 50

105 Guenter Treitel Remedies for Breach of Contract, A Comparative Account (Oxford University Press, Oxford, 1988) 73; Koch, above n 68, 348 .

106 Schlechtriem Commentary, above n 4, 553. 
This provision confirms that damages under the CISG are to be compensatory: "the promisee has a right to be fully compensated for all disadvantages he suffers as a result of the promisor's breach of contract."107 Since the starting point for the calculation of damages is the loss of the nonbreaching party, damages calculated by reference to the breaching party's profit or gain are not available under the CISG. ${ }^{108}$ According to the Secretariat commentary to this article, "the basic philosophy of the action for damages is to place the injured party in the same economic position he would have been in if the contract had been performed."109 This formulation mirrors the words used to describe the function of damages in Robinson $v$ Harman. ${ }^{110}$

Article 74 also includes a general rule on remoteness of damages, limiting the available damages to those which "the party in breach foresaw or ought to have foreseen at the time of the conclusion of the contract, in the light of the facts and matters of which he then knew or ought to have known, as a possible consequence of the breach of contract".

There are some small differences between the CISG and common law positions concerning the remoteness limitation. While Schlechtriem notes that the foreseeability requirement in the CISG can be traced back to the "Anglo-American model"111 based on Hadley $v$ Baxendale, ${ }^{112}$ he notes two differences. ${ }^{113}$ The first is that the CISG uses the objectively wider threshold of "possible consequence" instead of "probable consequence" as expressed in the second limb of the Hadley $v$ Baxendale test. ${ }^{114}$ As a result, the range of consequences arising from the breach for which damages may be available is wider under the CISG. The second difference is that the CISG uses the breaching party as the lens through which to gauge foreseeability whereas at common law foreseeability is determined by what is in the "reasonable contemplation of the parties". This is not a significant difference because what is in the "reasonable contemplation of the parties" will depend, apart from objectively determinable results, on what information the breaching party has received

107 Schlechtriem Commentary, above n 4, 553. However, restitutionary damages may be available according to applicable domestic law where uniform sales law does not apply: see Adras Chmorey Binyan v Harlow \& Jones GmbH [1988] RLR 235 (Supreme Court of Israel) and Daniel Friedmann "Restitution of Profits Gained by a Party in Breach of Contract" (1988) 104 LQR 383.

108 Schlechtriem Commentary, above n 4, 567.

109 Explanatory Note, above n 3, art 74, para 3.

110 Robinson $v$ Harman, above n 96, 855 Parke B.

111 Schlechtriem Commentary, above n 4, 554.

112 Hadley v Baxendale, above n 99.

113 Schlechtriem Commentary, above n 4, 567.

114 Hadley v Baxendale, above n 99, 354-5 Alderson B. 
from the non-breaching party in the course of their negotiations and dealings, ${ }^{115}$ and what the breaching party foresees under the CISG will depend on exactly the same thing. ${ }^{116}$

Articles 75 and 76 supplement article 74 by providing the means of calculating damages in certain defined cases after avoidance of the contract has occurred. Article 77 provides the general rule that the non-breaching party must take reasonable measures to mitigate the loss resulting from the breach.

This article is not the forum in which to criticise the development of the common law rules relating to remoteness and the recovery of damages in general, but they were developed in the knowledge that the rule would apply to all types of contracts. In contrast, the CISG rules relating to damages were developed as a response to considerations particular to international sale of goods contracts and in light of the reality of modern trade, as well as drawing on the combined experience of a number of legal systems. As noted above, the differences that exist are minor and, therefore, it is argued, should not be considered an obstacle to adopting these rules domestically.

\section{Buyer's remedy of reducing the price}

In addition to the above remedies which are available to both parties, the buyer has available a further remedy. This is the ability to unilaterally reduce the price if the seller delivers nonconforming goods. This remedy is governed by article 50 , which provides that "[i]f the goods do not conform with the contract and whether or not the price has already been paid, the buyer may reduce the price in the same proportion as the value that the goods actually delivered had at the time of the delivery bears to the value that conforming goods would have had at that time." The remedy is subject to the seller's right to remedy any defect under articles 37 or 48 of the CISG.

This remedy should not be seen simply as an alternative method of calculating damages: ${ }^{17}$

Both remedies can be exercised separately or cumulatively. However, their function is totally distinct.

Damages are to compensate the buyer's losses, while reduction of the price tends to prevent the seller

from getting a windfall. The seller should receive proportionately less than the price he would have

received for conforming goods. The buyer, having chosen so, should have to pay proportionately less for

keeping the goods delivered.

Despite the view of some authorities, ${ }^{118}$ this remedy does have a counterpart in common law countries. Section 54(1)(a) of the Act provides that where there is a breach of warranty by the seller , the buyer may set up against the seller the breach of warranty in diminution or extinction of the

115 Beale Chitty on Contracts, above n 22, 1453-1456.

116 Schlechtriem Commentary, above n 4, 568-569.

117 Michael Will in Bianca-Bowell Commentary on the International Sale Law, above n 30, 371.

118 Explanatory Note, above n 3, art 50, para 3. 
price. Such a remedy is unilateral in the sense that the buyer may choose not to pay the purchase price and can set up the diminution or extinction as a defence if the seller sues for the unpaid price. $^{119}$

Ultimately, it must be accepted that there are differences between the Act and the CISG. However, the CISG and the Act are not wholly dissimilar even if the CISG may provide a completely different remedy in some circumstances than that available under the Act. It cannot be said that circumstances may exist in which a remedy is available under one regime but in which no remedy is available under the other. It is simply that the remedy given under each regime may be different depending on the facts.

Overall, it would not be injurious to overhaul the New Zealand scheme of remedies for the breach of sale of goods contracts. In the author's opinion the benefit of having one complete law relating to all sales of goods, whether domestic or international, outweighs the detriment of having slightly different rules concerning sale of goods contracts as opposed to other contracts.

Those who support the condition-warranty distinction object to the CISG's fundamental breach rule, arguing that it is too dependent on consequences of the breach and not dependent enough on the intentions of the parties as expressed in the contract. There can be no real objection to the CISG rule on this ground for two reasons. First, there is nothing preventing the parties from setting out expressly exactly what will justify termination of the contract regardless of the consequences of the breach. Secondly, Parliament has already demonstrated by passing the Contractual Remedies Act 1979 that it is happy for cancellation (the Contractual Remedies Act's equivalent of termination) of contracts to be dependent on the consequences of the breach being substantial. ${ }^{120}$ It may be that under the Contractual Remedies Act 1979 the standard of substantiality is slightly less than that required by the CISG, but the policy behind the two regimes is in this respect the same. As a result, the Contractual Remedies Act 1979 and CISG are closer in terms of their underlying philosophy than the Contractual Remedies Act 1979 and the Sale of Goods Act 1908 are. Although they are expressed differently, the CISG and Contractual Remedies Act 1979 will sit alongside each other better than the current scheme.

Therefore, while there would continue to be a distinction between sales of goods and other sales, in consideration of trade in New Zealand a better reform option is to remove the current distinction between international and domestic sale of goods. This would mean that those who trade both within and outside of New Zealand have a consistent legal framework to consider regardless of the place of business of the other contracting party.

119 Sutton, above n 19, 670-671.

120 Contractual Remedies Act 1979, s 7(4)(b). However, the contract may still be cancelled if the parties have expressly or impliedly agreed that the performance of the term is essential: Contractual Remedies Act 1979, s 7(4)(a) 
That is the primary reason why it is proposed that New Zealand seriously consider reforming the law relating to sales of goods by adopting the remedies regime in the CISG, rather than the code in the Contractual Remedies Act 1979. The CISG remedies regime has the benefit of being devised with reference to a large number of legal systems. The drafters were free to pick and choose the most effective remedies within those legal systems and meld them into one coherent practical code. Further, the remedies are chosen with important considerations of international trade in mind. The CISG provisions are better suited to today's world than the current New Zealand position.

The penultimate section will now consider the trade and economic reasons for adopting the CISG domestically.

\section{TRADE IN NEW ZEALAND}

New Zealand has a small economy, ${ }^{121}$ but one which is strongly trade-oriented. ${ }^{122}$ Despite this, a healthy growth was recorded in exports for the year ending April 2005. The value of New Zealand's merchandise exports in that time was NZ\$31.1 billion, an 8.3 per cent rise from the previous year. ${ }^{123}$

In 1992 the New Zealand Law Commission highlighted a number of statistics concerning New Zealand's external trade as indicative of a trend away from trading only within the Commonwealth to trading on a more global basis. It stated that, as at $1990::^{124}$

28 percent of New Zealand's external trade is now with five northern Asian economies (Republic of Korea, China, Hong Kong, Japan and Taiwan), 18 percent with the European community (including the United Kingdom), and 18 percent with North America. There are also important trade links with other countries in Asia (Indonesia, Malaysia and Singapore), Latin America (Mexico), Middle East (Iran) and Eastern Europe (Russia).

It concluded that: $:^{125}$

New Zealand export trade is accordingly now potentially subject to a great variety of legal systems, some very different from the legal systems of New Zealand and those of the small groups of States with which New Zealand traded for so long.

121 It had the fourth lowest GDP of Organisation for Economic Co-operation and Development (OECD) countries as at 13 April 2005: see OECD <http://www.oecd.org> (last accessed 3 August 2006).

122 Market New Zealand Country and Economy Brief: New Zealand <http://www.marketnewzealand.com> (last accessed 3 August 2006).

123 Overseas Merchandise Trade (Exports) April 2005: see Statistics New Zealand < http://www.statistics .govt.nz> (last accessed 3 August 2006).

124 New Zealand Law Commission, above n 33, para 7.

125 New Zealand Law Commission, above n 33, para 7. 
This trend was a major consideration behind the Law Commission's recommendation that New Zealand accede to the CISG, and it is a trend that can still be seen today. For the year ended April 2005,14 of New Zealand's top 20 export markets, ${ }^{126}$ and 9 out of the top 10, were countries that had adopted the CISG.

However, due to a range of factors such as geographical isolation and small population, no other economy has such high transportation and communication costs. ${ }^{127}$ Furthermore, "New Zealand industries and firms have relatively high average costs ... that are in accord with poor productivity and/or absence of economies of scale." 128

These statistics and trends provide a strong basis for implementing the rules of the CISG as domestic law. Such a step would have the effect of harmonising the legal position of companies who do business within the New Zealand domestic market but who want or need to trade in overseas markets, lowering compliance costs. It would help New Zealand companies in achieving the economies of scale necessary to compete in overseas markets.

\section{OTHER JURISDICTIONS}

Given that the CISG is an international document, it is instructive to look overseas to see whether other states have considered it prudent to harmonise the law applying domestically and internationally. Adopting the rules and principles of the CISG domestically would not be an unprecedented step. For instance, the People's Republic of China and the successor States of Yugoslavia have codified their domestic sale of goods law using the CISG as a model. ${ }^{129}$ In addition, Germany has recently undertaken major reform of the whole of its law of obligations, with

126 These were Australia, United States of America, Japan, People's Republic of China, United Kingdom, Republic of Korea, Germany, Taiwan, Canada, Philippines, Hong Kong (SAR), Malaysia, Belgium, Indonesia, Italy, Mexico, France, Singapore, Saudi Arabia and Thailand. See Statistics New Zealand $<$ http://www.statistics.govt.nz $>$ (last accessed 3 September 2005).

127 Terence Arnold, David Boles de Boer and Lewis Evans "The Structure of New Zealand Industry: Its Implications for Competition Law" in Mark N Berry and Lewis T Evans (eds) Competition Law at the Turn of the Century: A New Zealand Perspective (Victoria University Press, Wellington, 2003) 26.

128 Arnold, Boles de Boer and Evans, above n 127, 39.

129 Schlechtriem Commentary, above n 4, 7. 
the Schuldsrechtsreform ${ }^{130}$ coming into force on 1 January 2002. ${ }^{131}$ In terms of remedies, it for the most part adopts the CISG remedies model. ${ }^{132}$

Yet perhaps the most helpful example of domestic reform of sale of goods law is provided by the Scandinavian States with the passing of the Scandinavian Sale of Goods Acts (Finland 1987, Norway 1988, Sweden 1990) which largely adhere to the principles of the CISG. It is helpful because in the 1980s the Scandinavian legislators were in much the same position as the one in which the New Zealand legislature finds itself today.

In 1976, a law commission presented a draft Act modernising the previous sale of goods laws of 1905-1907, "particularly with respect to avoidance and damages in case of breach". ${ }^{133}$ However, before that proposal was acted upon, the CISG was adopted at the 1980 United Nations diplomatic conference, and ratified by all of the Scandinavian States in the late 1980s. As Ramberg puts it: ${ }^{134}$

The legislators in Scandinavia were now facing a difficult problem. Should modernised Acts from 1905-1907 be enacted for domestic and intra-Scandinavian trade, although this would result in a "twotrack" system, one track for such contracts and another one for contracts of sale within the scope of application of the CISG? Or should, alternatively, the proposed modernization [sic] of the old Acts be set aside in favour of new proposals on the basis of the CISG with as few deviations as possible?

The response of the legislators was to adopt a "one-track" system, harmonising as much as possible the domestic law with the principles and rules of the CISG. The alternative, it was thought, would lead "to increased transaction costs and sometimes rather unexpected differences in similar contracts". 135

130 Reform of the German Law of Obligations.

131 See generally Peter Schlechtriem "The German Act to Modernize the Law of Obligations in the Context of Common Principles and Structures of the Law of Obligations in Europe" (Oxford University Comparative Law Forum, Oxford, 2002) 2; Hans Schulte-Nölke, above n 4; Reinhard Zimmerman "Breach of Contract and Remedies under the New German Law of Obligations" (Centre for Comparative and Foreign Law Studies, Rome, 2002).

132 See Andreas Heldrich and Gebhard M Rehn "Modernisation of the German Law of Obligations" in Nili Cohen and Ewan McKendrick (eds) Comparative Remedies for Breach of Contract (Hart Publishing, Portland, 2005) 123, 130; Dagmar Coester-Waltjen "The New Approach to Breach of Contract in German Law" in Nili Cohen and Ewan McKendrick (eds) Comparative Remedies for Breach of Contract (Hart Publishing, Portland, 2005) 135, 135; and Zimmerman, above n 131, 7-8.

133 Jan Ramberg "The New Swedish Sales Law" (Centre for Comparative and Foreign Law Studies, Rome, 1997).

134 Ramberg, above n 133, 2.

135 Ramberg, above n 133, 2. 
The parallels between this example and the current New Zealand situation are striking. In 1979 Parliament considered a modernisation of the law relating to termination for breach of contract, and passed the Contractual Remedies Act 1979 with respect to all contracts other than sale of goods contracts. In 1994 it adopted the CISG, thereby accepting a two-track system with regard to sales of goods. ${ }^{136}$ In 1993, the New Zealand Law Commission suggested that Parliament repeal the Sale of Goods Act 1908 in favour of the Contractual Remedies Act 1979. Such a step would perpetuate the "two-track" sale of goods system which Sweden rejected. Instead, New Zealand should move towards a one-track sale of goods system by harmonising the law relating to remedies in the case of breach with the CISG position.

\section{CONCLUSION}

There are currently four statutory codes governing the remedies for breach of contracts of sale in New Zealand, ${ }^{137}$ a framework which is "obviously unsatisfactory". ${ }^{138}$ Instead, the regime for remedies for sale of goods contracts in the CISG should be adopted as the domestic law of New Zealand relating to sales of goods. This would have the effect of retaining the distinction made by the Contractual Remedies Act 1979 between sale of goods contracts and other contracts, but removing the distinction between domestic and international sale of goods.

There is no doubt that the law relating to sale of goods contracts in New Zealand has an established and secure place in the law, built largely on what are by now well understood and therefore certain rules. However, there is no point retaining rules simply for certainty's sake where they lead to manifestly unjust results or where they are out-dated. Instead, the remedies contained in the CISG are better able to do justice as between the parties. Compared to the provisions of the Sale of Goods Act 1908, the provisions of the CISG are flexible, fair, and take better account of the considerations which underlie the purpose and the reality of modern international trade.

Many argue that the CISG does not provide enough certainty as to when a party is entitled to terminate the contract for breach. ${ }^{139}$ Such arguments are misguided. In fact, uncertainty exists in the current New Zealand legal position. The outmoded provisions of the Sale of Goods Act 1908 have forced the increasing categorisation of contractual terms as intermediate because the Act does not adequately provide for the demands of modern trade. Although the CISG's concept of fundamental breach is similar to that of an intermediate term, it provides a more certain legal position due to the high threshold it imposes.

136 This is a four-track system when the Contractual Remedies Act 1979 and Consumer Guarantees Act 1993 are taken into account.

137 Dugdale and Walker, above n 2, 112.

138 Dugdale and Walker, above n 2, 111.

139 Guest, above n 59, 965-6; Nicholas, above n 73, 242-3. 
Strong economic policy factors support this proposed reform. New Zealand has a small economy. Its geographical isolation and small population cause relatively high average operating costs. ${ }^{140}$ Harmonising New Zealand's domestic sale of goods law with the law applicable in most of the overseas markets in which it trades would benefit New Zealand companies by reducing legal compliance costs. In its 1993 paper the New Zealand Law Commission agreed that "[a] degree of parallelism between the laws for international and domestic transactions is attractive."141

Further, adopting the CISG provisions in relation to domestic sale of goods contracts would not be unprecedented. Many states have begun adopting the CISG as their domestic sales law. ${ }^{142}$ Importantly, the People's Republic of China, one of New Zealand's top four trade partners and a potential free trade partner, ${ }^{143}$ has recently brought its law in line with the principles underlying the CISG.

The Law Commission framed the issue this way in its 1993 paper: ${ }^{144}$

Should a manufacturer shipping goods from Whangarei be in a different legal position depending on whether the purchasing wholesaler is in Wellington, Wollongong or Wilmington?

The answer must be "no".

140 Arnold, Boles de Boer and Evans, above n 127, 39; David Skilling The Importance of Being Enormous: Towards an Understanding of the New Zealand Economy (Preliminary Draft to NZ Treasury, 30 July 2001).

141 New Zealand Law Commission, above n 33, para 142.

142 Schlechtriem Commentary, above n 4, 7.

143 Ministry of Foreign Affairs and Trade, New Zealand, and Ministry of Commerce, China A Joint Study Report on a Free Trade Agreement between China and New Zealand, available at Ministry of Foreign Affairs and Trade $<\mathrm{http}: / /$ www.mfat.govt.nz $>$ (last accessed 3 August 2006).

144 New Zealand Law Commission, above n 33, para 142. 
